\title{
REVIEW
}

\section{Status updates of Newcastle disease and amelioration effects of medicinal plants against Newcastle disease virus: A review}

\author{
A. ASHRAF 1 , S. MAHBOOB 2 , R. ANDLEEB ${ }^{1}$, M. U. IJAZ ${ }^{3}$, M. S. SHAH ${ }^{4}$
}

\begin{abstract}
${ }^{1}$ Department of Zoology, Government College University Faisalabad, Allama Iqbal road, 38040, Faisalabad, Pakistan; ${ }^{2}$ Department of Zoology, College of Science, King Saud University, Riyadh, Saudi Arabia; ${ }^{3}$ Department of Zoology Wild life and Fisheries, University of Agriculture Faisalabad, Pakistan; ${ }^{4}$ Animal Sciences Division, Nuclear Institute for Agriculture and Biology (NIAB), Faisalabad, Pakistan
\end{abstract}

\begin{abstract}
Summary. - Recently, medicinal plants are achieving great interest because of their use in ethno medicine treatment of different common diseases and also other medicinal assertions are now reinforced by comprehensive scientific evidence. Almost 82 research articles and abstracts published, so far, were screened for evaluating antiviral efficiency of various plant samples and 23 different plants were found to be traditionally used against Newcastle disease (ND). ND is a most transmissible viral disease of avian species caused by virulent strain of Avula virus from the Paramyxoviridae family. The first epidemic of ND was perceived in Java, Indonesia and England in year 1926. ND causes great economic loses to the commercial poultry farmers around the world. Medicinal plants are traditionally used in the control of viral or other diseases and infections. Plants have been found useful in treating many microbial diseases in man and animals caused by bacteria and viruses. The ability to synthesize compounds retaining antiviral potential by secondary metabolism makes plants a vital source of pharmaceutical and therapeutic products, which can reduce chemotherapeutic load in birds. Current studies signify that the natural products posses a rich potential source of new antiviral compounds. Further ethnobotanical studies and laboratory investigations are established to identify species having potential to improve ND control.
\end{abstract}

Keywords: Newcastle disease; poultry; medicinal plants; antiviral efficacy; phytochemicals

\section{Contents:}

1. Introduction

1.1 Etiology of NDV

1.2 Epidemiology of NDV

1.3 Clinical signs

1.4 Transmission

2. Global distribution of Newcastle disease

3. Economic losses in Pakistan

4. Pathophysiology of NDV

E-mail: asmabinm@gmail.com; phone: +92-03326735319.

Abbreviations: ECE = embryonated chicken eggs; ND = Newcastle disease vNDV = velogenic NDV; NDV = ND virus; $\mathrm{vvNDV} \mathrm{=} \mathrm{vis-}$ cerotropic velogenic NDV; nvNDV = neurotropic velogenic NDV; OIE $=$ Office International des Epizooties
5. Prevention and mechanisms in the treatment of NDV

5.1 Plants used in NDV treatment

6. Overview of plant species used as anti-NDV treatment

6.1 Azidarachta indica

6.2 Acacia nilotica

6.3 Adansonia digitate

6.4 Anthocleista nobilis

6.5 Aloe secundiflora

6.6 Aloe hijazensis

6.7 Artemisia annua L.

6.8 Curcuma longa

6.9 Commiphora swynnertonii

6.10 Cladosiphon okamuranus

6.11 Capsicum spp. 


\subsection{Cucumis metuliferus \\ 6.13 Cassia tora \\ 6.14 Euphorbia ingens \\ 6.15 Echinacea purpurea \\ 6.16 Glycyrrhiza glabra \\ 6.17 Momordica balsamina \\ 6.18 Moringa oleifera \\ 6.19 Nauclea latifolia \\ 6.20 Ocimum sanctum \\ 6.21 Psidium guajava \\ 6.22 Thymus vulgaris \\ 6.23 Withania somnifera \\ 7. Conclusion}

\section{Introduction}

Newcastle disease (ND) is an important viral disease of poultry and other avian species regardless of their age and sex (Yune and Abdela, 2017). ND is often called Ranikhait as vernacular name in Pakistan (Narayanan et al., 2010). First it was identified in Indonesia, Java and England in 1926 by Office International des Epizooties (OIE, 2012). However, there was an earlier report of same outbreak in Central Europe. ND was not reported in poultry before the year 1926. The name "Newcastle disease" (after the first outbreak) was professed by Doyle as a temporary measure to avoid confusion with other diseases (Doyle, 1935). ND is critical health problem in avian industry due to high mortality and morbidity worldwide (Khan et al., 2010). Due to the severe nature of ND and the related consequences, NDV is counted in "listed" agents (reportable disease) by OIE (Boynukara et al., 2013). OIE has the duty of ND epidemics notification (Cao et al., 2013), when it meets certain criteria of virulence (Munir et al., 2012).

\subsection{Etiology of NDV}

Newcastle disease virus (NDV) is a non-segmented, single-stranded, negative-sense, enveloped RNA virus belonging to the Paramyxoviridae family, the Paramyxovirinae subfamily and the genus Avula virus (Ashraf et al., 2016). The virus exists in ten serotypes APMV-1 to 10 and NDV is synonymous with avian paramyxovirus type 1 (APMV-1). Only diseases with the virulent type APMV-1 are accounted as ND (Waheed et al., 2013). NDV viral particles are observed by electron microscopy as pleomorphic, varying from roughly spherical to filamentous with varying lengths (Catroxo et al., 2011). Spikes of approximately 8-12 $\mathrm{nm}$ are present on the viral surface. The "herring bone"like nucleocapsid (about 13-18 $\mathrm{nm}$ in diameter) can be seen either free or emerging from disrupted viral particles
(Alexander, 1997). Genome with length of around 15.2 $\mathrm{kb}$ (Zhang et al., 2012) encodes for six structural and two non-structural proteins (Choi et al., 2010). Six proteins, nucleoprotein, large RNA polymerase (L), fusion protein (F), hemagglutinin-neuraminidase, matrix protein $(\mathrm{M})$ and phospho-protein, are encoded in 3 ' to 5 ' direction (AlHabeeb et al., 2013). NP is most important protein which forms the nucleocapsid helical core of NDV and induces antibody production in chickens. $\mathrm{HN}$ and $\mathrm{F}$ proteins are most significant in identification and pathogenecity of the virus. F protein is important for pathogenic and virulence properties. $\mathrm{HN}$ is vital for attachment and penetrating the host cell (United States Animal Health Association-USA$\mathrm{HA}, 2008)$. On the basis of their pathological index NDV is divided into three pathotype groups, which are lentogenic, mesogenic and velogenic pathotypes. Lentogenic strains cause mild respiratory infections. Mesogenic strains cause nervous and respiratory signs with mortality rates dependent on age of susceptible species. Velogenic NDV (vNDV) is virulent strain which causes severe mortality. The velogenic strains may be divided into neurotropic velogenic NDV (nvNDV) or viscerotropic velogenic NDV (vvNDV) types (OIE, 2012). According to field studies in Pakistan, the incidence of velogenic type was 5\%, mesogenic type 55\% and lentogenic type $40 \%$ (Waheed et al., 2013). In severe cases the morbidity and mortality may reach up to $100 \%$.

\subsection{Epidemiology of NDV}

Newcastle disease is endemic to various parts of the world. NDV affects more than 250 species of 27 orders of birds. ND, the most serious poultry disease kills in average 70 to $80 \%$ of the unvaccinated rural poultry flocks every year. Many evidences show that all avian species are susceptible to NDV including cormorants, pigeons, chickens, turkeys, parrots, migratory waterfowl, penguins and shorebirds (Institute for International Cooperation in Animal Science - CFSPH, 2016). Cormorants, pigeons, and imported psittacine are most susceptible to this virus and are also the major transmitters of NDV in poultry (Patti, 2014). Chickens are very vulnerable while the aquatic birds are the most resistant. Tame and exotic birds are mostly resistant (Erickson et al., 1977). Virus shedding is short in Galliformes and different song birds while long lasting shedding is seen in Columbiformes (pigeons and doves) and Passeriformes with damaged kidneys (Kaleta and Baldauf, 1998).

Humans are also susceptible to NDV. NDV causes conjunctivitis in individuals highly exposed to virus for a long time. Mostly, laboratory workers and vaccinators are infected by this virus. In humans mild or self-limited influenza like symptoms with fever and headache have been diagnosed (Alexander, 2000; OIE, 2012). 


\subsection{Clinical signs}

The clinical signs are dependent upon age and species of the host, viral strain, immune status of the host and environmental conditions (Al-Habeeb et al., 2013). The clinical signs of ND are categorized into reproductive, respiratory, nervous and enteric signs.

Clinical signs of reproductive organ infection include: drop in egg number, misshapen eggs, rough or stumpy shelled eggs, and decrease in albumen quality. Sometimes egg production returns to normal level after 3-4 weeks (Yan et al., 2011).

The respiratory infection signs include mild sneezing and gasping for air. More serious signs are sneezing, coughing, nasal discharges and respiration distress with open beak breathing. Inhaling can be accompanied by a rattling sound. Head shaking, with dislodged mucus form the respiratory airways and sometimes mucopurulent conjunctivitis may appear (Fig. 1). Nervous infection symptoms are tremors, paralyzed wings and legs, twisting and circling of neck (Fig. 2) (Bhaiyat et al., 1994). In critical cases, death occurs immediately without the appearance of any signs (Ashraf and Shah, 2014). The enteric infection is accompanied by greenish diarrhea (McFerran and McCracken, 1988).

Viscerotropic velogenic (extremely virulent type) type of disease may appear suddenly, with high mortality with absence of other clinical signs (Beard and Hanson, 1984). Mortality is up to $100 \%$ in virulent forms of the disease (Martin, 1992). More often death occurs within 4-8 days preceded by weakness and fatigue. Varying levels of depression and inappetence are observed. Sometimes abandonment of egg laying may occur. Eggs display an altered shape, color and watery albumen of egg. Other signs as edema of head and

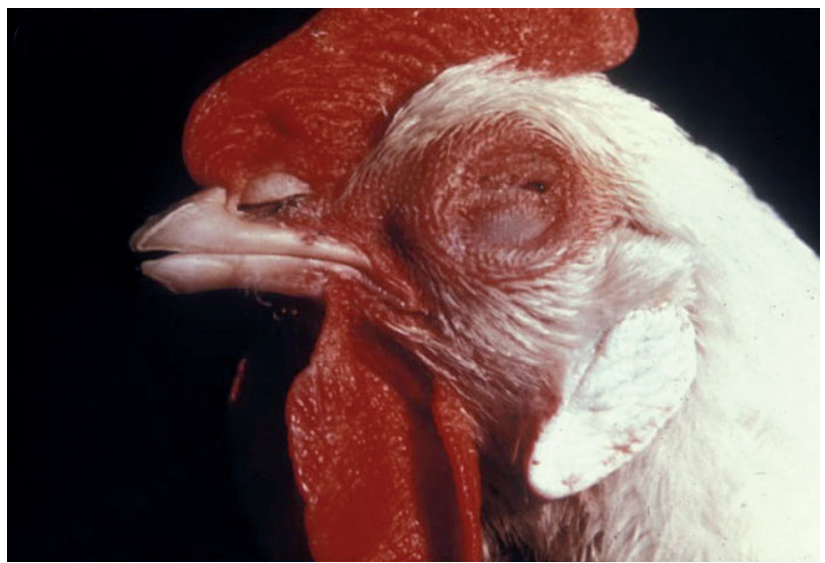

Fig. 1

Respiratory clinical signs of Newcastle disease of chickens Conjunctivitis (Lucas and Jamroz, 1961).

tissues around the eyes, increase in respiration rate, watery greenish diarrhea, sometimes with blood may be observed. The common symptoms begin with loss of appetite, thirst, dehydration, emaciation with high body temperature. Somnolence, fluffed feathers, listlessness, huddling, progressing to complete depression, change of voice, diffuse cyanotic coloration of the skin especially in comb and wattles may be seen after infection by this virus type (Fig. 3) (McFerran and McCracken, 1988).

In the mesogenic type, mortality is up to $50 \%$ with acute respiratory disease and decline in egg production with low quality which may occur for about 1-3 weeks (Hadipour et al., 2011). Respiratory signs of coughing, sneezing, but no gasping and rale is present in low virulence infections.

(a)

(b)
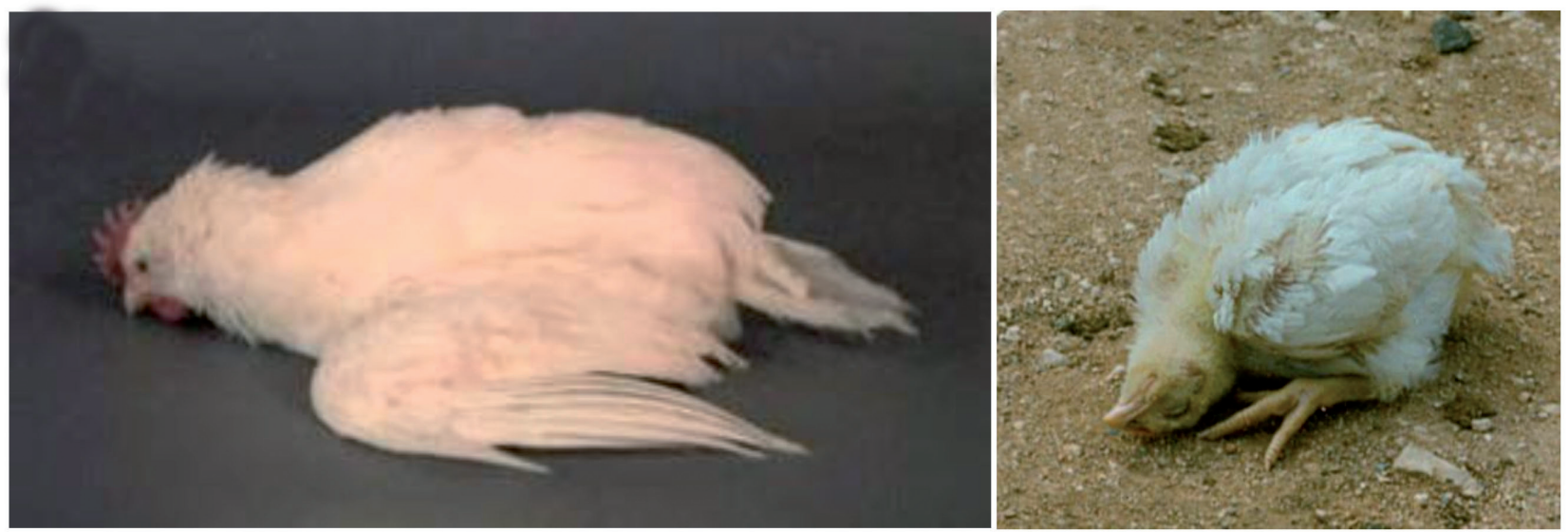

Fig. 2

Nervous clinical signs of Newcastle disease of chickens

(a) Paralysis (neurotropic); (b) twisted neck (nervous disorder) (http://partnersah.vet.cornell.edu/avian-atlas/taxonomy/term/562). 

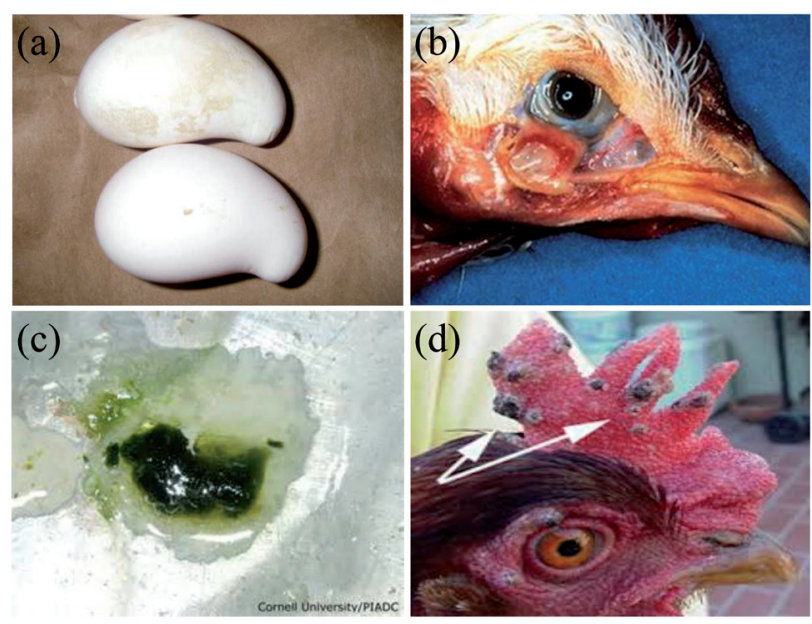

Fig. 3

Velogenic infection clinical signs of Newcastle disease of chickens (a) Misshappen eggs (Piller, 2010); (b) internal and external hemorrhage (Herenda and Chamber, 1994); (c) green watery diarhhea (Lucas and Jamroz, 1961); (d) comb cyanosis (Admin, 2017).

Nervous symptoms are not common (Jordan, 1990). Death is usually rare in fowl, except in very young and vulnerable birds, or in worsened conditions (Alexander, 1993).

In lentogenic disease, adults are generally not harmed. In young birds, severe respiratory disease complications can be seen, often resulting in death. Vaccination or infection of broilers infected by these viruses can progress to septicemia (Alexander, 1993).

Shedding of the virus mostly occurs in birds before and after the clinical sign appearance. Virus shedding appears anywhere from one week to a year depending upon the species of the bird, e.g. chickens are more prone to infection than ducks (Kapczynski et al., 2013). The pigeons infected by variant of paramyxovirus (PMV1) can cause morbidity up to $80 \%$. Ducks and geese are usually resistant to NDV with morbidity less than $10 \%$. Canaries are susceptible, showing a mild disease, although the mortality varies from $20 \%$ to 30\% (Canadian Food Inspection Agency - CFIA, 2014).

\subsection{Transmission}

The disease is spread by direct contact with feces, droppings, respiratory secretions, egg shells and feathers of infected birds. It can also be transmitted from smuggled birds from area where NDV is endemic (Perozo et al., 2008). Movement of contaminated people, clothes, trays and vehicles can also transmit the virus (Hitchner, 2004). Air borne transmission is most common way of infection (Li X, 2009). Transmission from infectious feces occurs by insects, rodents, fleas, dogs or scavengers (Ullah et al., 2004).
The vaccination of NDV is helpful to prevent the disease but not infection and excretion of the virus. However, vaccination may significantly reduce the time of virus shedding (Alexander et al., 1999). Vaccines and antibiotics result in the development of resistance in birds against these allopathic medicines, and residues of drugs in both eggs and meat, are detrimental to human health. The practice with different medicinal plants to control this virus is considered as a compatible approach, because nowadays plants have been involved in control of various infectious and non-infectious ailments. Secondary metabolites present in plants have been considered as innovative antiviral agents, and can lessen chemotherapeutics load in birds. Therefore, the search for highly selective and non-toxic antiviral plant compounds is urgently needed in view of spread of ND throughout the world (Ocazionez et al., 2010).

\section{Global distribution of Newcastle disease}

Since in 1926 form its recognition, ND is regarded as being highly prevalent in many countries and occurs worldwide. Virulent NDV is endemic to Asia, Africa, South and North America, most parts of Mexico, Europe, Canada, and USA (Naveen et al., 2013). All continents of the globe continually document the presence of ND (Munir et al., 2012). About 20 years after its recognition it becomes a panzootic (Fig. 4).

The first epidemic outbreak in Java, Indonesia and in Europe from Newcastle-upon-Tyne, England occurred in 1926 and spread very slowly across the globe until late 1950s (Qiu et al., 2011). ND outbreak in Middle East began in late 1960s and spreads to other countries untill 1973 and in 1981, ND reached also Europe (Mase et al., 2002). The third drastic outburst appeared in Middle East during late 1970's. Then disease progressed until late 1980s in Far East, Europe and South Africa (Qiu et al., 2011). In early 1990's incidence of this disease increased in Western Europe culminating with 239 occurrences in European Union countries in 1994.

ND has been reported in 1995 in wild birds in Canada, and in 2002-2003, an epidemic outbreak in California resulted in great losses that were estimated at 5 billion USD and the death of more than 3 million birds. Currently, in the United States, Western Europe, and Canada the disease is under control, however it endures in some regions of Asia, South America and Africa. The risk of reappearance of an outbreak is still high, since wild birds are asymptomatic carriers of the virus (CFIA, 2014).

\section{Economic losses in Pakistan}

Geographically, Pakistan is situated $\left(33^{\circ} 40^{\prime} \mathrm{N}\right.$ and $\left.73^{\circ} 10^{\prime} \mathrm{E}\right)$ at the crossroads of the central areas of Asia. From 2009 to 


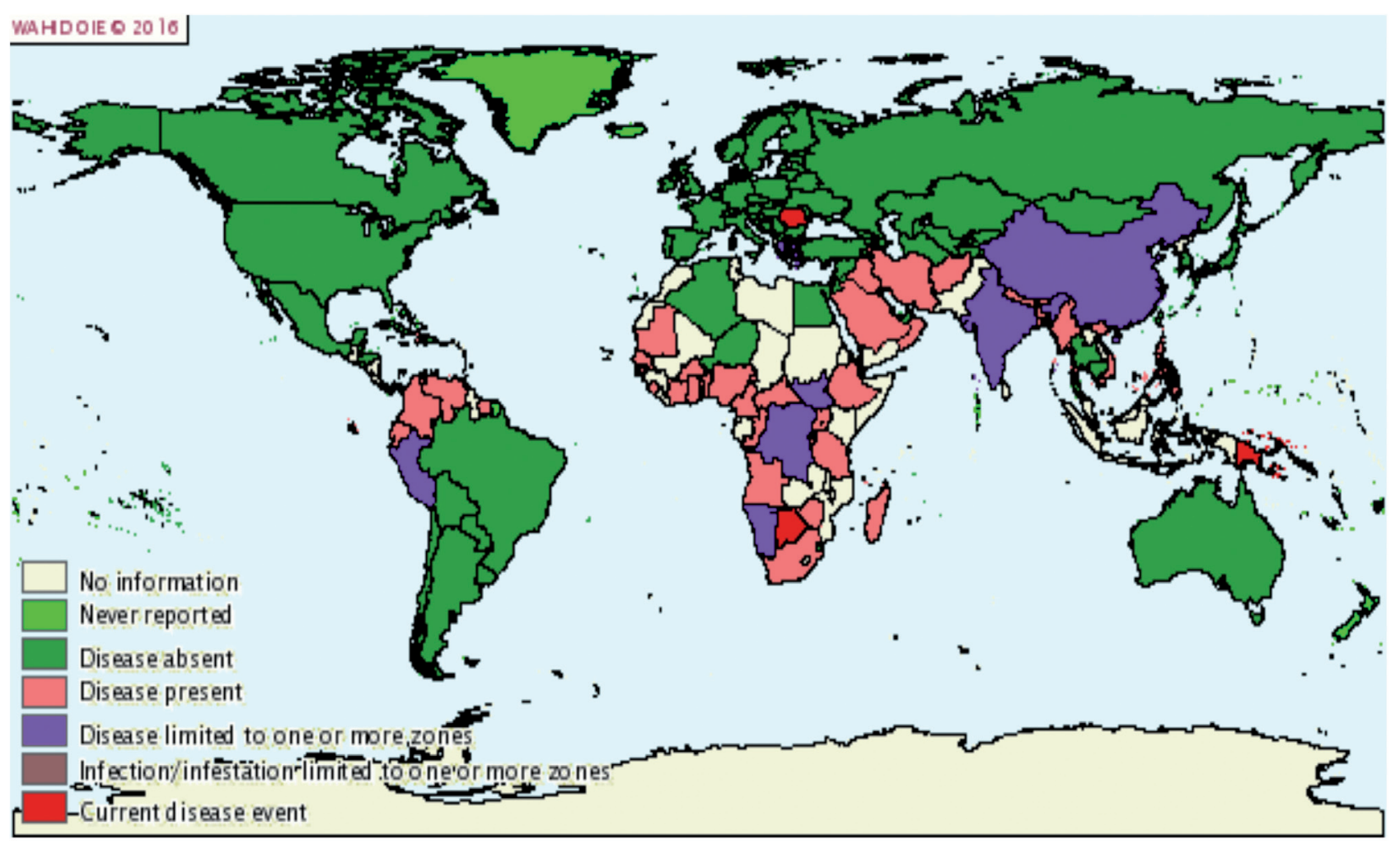

Fig. 4

Prevalence of Newcastle disease in 2015

World Animal Health Information Database (WAHID Interface), Version 1 Copyright @ World Organization for Animal Health (OIE); www.old.caribvet. net/en/diseases/newcastlediseases/geographical-distribution.

mid 2012, high amount of ND outbreaks have been documented (OIE, 2013). ND causes massive economic losses to commercial poultry. In Pakistan a periodic form of ND appears throughout the year; however only a limited number of epidemics are reported (Munir et al., 2012).

In the period of inadequacy, poultry eggs and meat are valuable protein source in Pakistan. Poultry industry is the back bone of rural as well as commercial economy in Pakistan. In Pakistan there is around 1105,91 millions of poultry, among which rural poultry is about 152,44 millions. It contributes to an energetic part of the village economy with the participation of up to 3,611 million eggs and 100,41 metric tons of the total poultry meat (Khan et al., 2010). This sector is source of work and income for about 1,5 million people. Its abundance in agriculture is $56.3 \%$, while the livestock forms only $11.5 \%$. Poultry had a $28.5 \%$ share in meat production and in GDP at constant cost factor of $11.8 \%$. Fast growth of about $8-10 \%$ every year in poultry sector, indicates its inherent prospective. According to currently conducted survey, the present investment in the Pakistan poultry industry is about 200 billion USD (ESP, 2015-2016).
In Pakistan ND is the top ranking infection of rural poultry (Khan et al., 2011). ND is reported as main respiratory distress causing agent in different areas (Ahmed et al., 2009). Velogenic NDV and influenza with secondary bacterial infection were involved in epidemics in Smaundari, Kamalia, and Gojra in province Punjab. Incidence of ND in Faiyumi chickens and native breeds of rural poultry in district Sheikhupura has been estimated to 40.33\% (Mustafa and Ali, 2005). In Faisalabad, the seroprevalence of NDV antibodies in broilers was $98.07 \%$ and in layers $100 \%$ (Numan et al., 2005). According to Mustafa Kamal, convener of the disease control committee of the Pakistan Poultry Association, farmers in this country have faced losses of more than five million USD since an outbreak of NDV in 2011. Mortality ratio still occurs at $10-20 \%$ in the cities of the provinces of Punjab and Khyber PakhtunKhwa, Quetta and Karachi (Kamal, 2013). During 2012, in Jallo Wildlife Park Lahore, Pakistan the virulent velogenic strain of NDV took lives of 190 peacocks, and caused $100 \%$ mortality in other birds (Munir et al., 2012) (Fig. 5). 


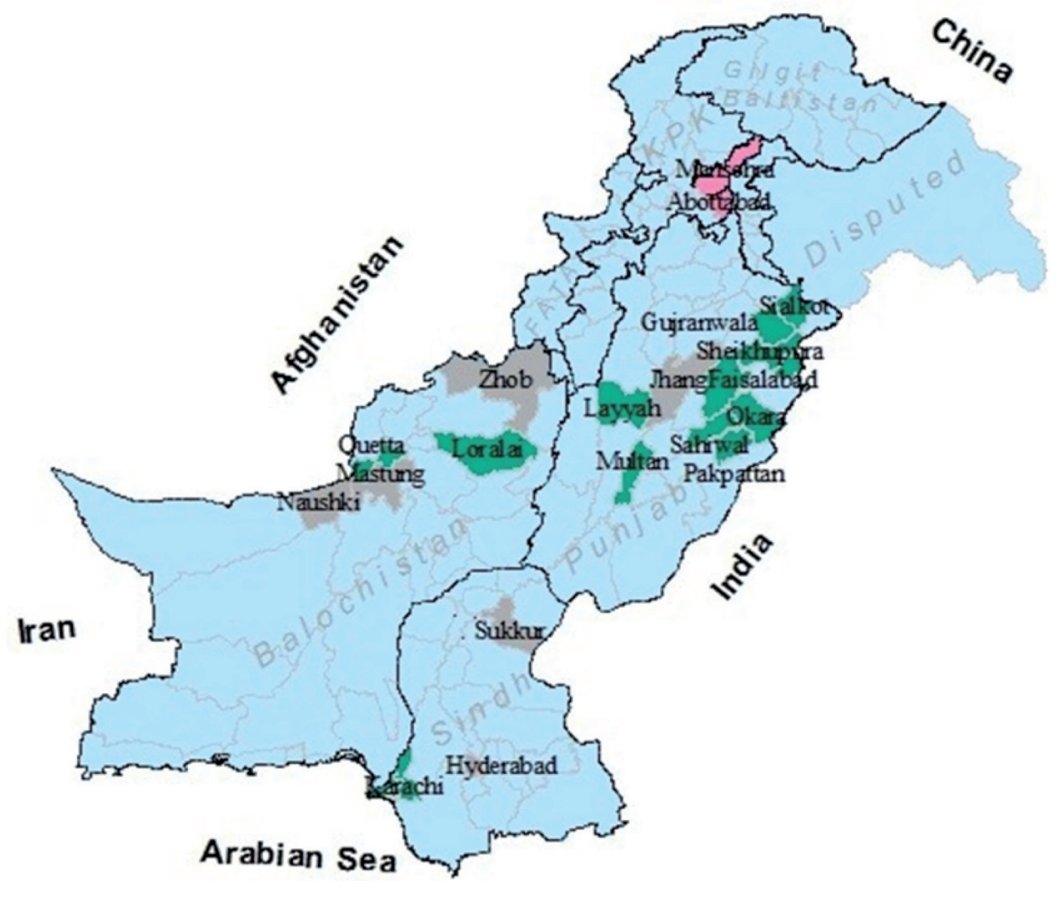

Fig. 5

Geographical sites of NDV in Pakistan (Shabbir et al., 2013)

Plants were used as traditional medicine and petition for natural and herbal products since early civilization and recently their use has been reintroduced. Approximately $70-95 \%$ of the people in world depend on herbs for primary dealing of ailments (Robinson and Zhang, 2011). It was observed that $25 \%$ of total drugs used in the world contain antivirals from plants. The $60 \%$ of anticancer and $75 \%$ of infectious disease drugs are the derivatives of natural ingredients which are more suitable, less toxic, and less expensive than synthetic drugs. Investigation conveyed that potential antiviral components from plants are present in crude extracts, essential oils or purified compounds from which secondary metabolites like flavonoid, phenolic and anti oxidising compounds are used as antiviral agents for NDV (Newman and Cragg, 2007).

\section{Pathophysiology of NDV}

The virus enters the organism by respiratory or intestinal tract. In trachea the virus spreads by cell-to-cell infection or ciliary actions. Subsequent spread is largely governed by strain virulence. While lentogenic strains are present only at low titers in the circulation, mesogenic strains spread to kidney, lungs, bursa, and spleen. Virulent virus can be found within 22 to $44 \mathrm{~h}$ in practically all tissues, with highest tit- ers in the thymus, and lowest in muscles and brain. During second multiplication, the virus is released into blood circulation again and the clinical symptoms appear. The virus is excreted into environment by feaces. Some viruses reach the target organs very fast and the birds die without showing any symptoms of disease (Kouwenhoven et al., 1993). Incubation period depends upon the host species, age and strain of the virus. The OIE (2013) gives 21 day period duration for ND. After natural exposure to vNDV, incubation from 2-5 days or longer has been reported, with an average of 5-6 days (Alexander and Senne, 2008).

Replication, transcription and translation of NDV takes place in cytoplasm of the host cell, viral constituents accumulate at the plasma membrane and the virus is released by budding (Zanetti et al., 2003). The NDV particles contain precursor glycoprotein F0, which is an important pathogenic marker for NDV (Madadgar et al., 2013). F0 is cleaved into F1 and $\mathrm{F} 2$ proteins. Two pairs of basic amino acids of $\mathrm{F} 0$ protein are cleaved by host proteases (Pham et al., 2005). Trypsin is responsible for cleavage of $\mathrm{F} 0$ and infectivity induction in non-infectious viruses (Nagai et al., 1976). Cleavage of the F0 molecule was associated with the virulence of viruses in vivo. Viral particles containing $\mathrm{F}_{0}$ molecules are highly contagious for chickens. $\mathrm{F}_{0}$ can be cleaved by host's protease present in wide range of cells and tissues. This cleavage allows viruses to spread in the hosts' body and damage vital organs. Low 
Table 1. Antiviral activity of plant specific parts used against viruses

\begin{tabular}{|c|c|c|c|c|}
\hline No. & Plant name & Part used & Study attentive & References \\
\hline 1. & Azidarachta indica & leaves, stem & NDV & Waafa et al., 2007 \\
\hline 2. & Acacia nilotica & stem, leaves & NDV & Saeed, 2007 \\
\hline 3. & Adansonia digitata & bark & NDV & Sulaiman et al., 2011 \\
\hline 4. & Anthocleista nobilis & root & NDV & Ayodele et al., 2012 \\
\hline 5. & Aloe secundiflora & gel & influenza virus, NDV, HSV-1, HSV-2 & Waihenya et al., 2002 \\
\hline 6. & Aloe hijazensis & flower, leaves & NDV & Abd-Alla et al., 2012 \\
\hline 7. & Artemisia aпnиа $\mathrm{L}$. & flower, leaves, fruits & $\mathrm{NDV}$ & Liu and Genqiang, 2009 \\
\hline 8. & Curcuma longa & aerial parts & MDV, NDV, immune response & Madbouly et al., 2011 \\
\hline 9. & Commiphora swynnertonii & $\begin{array}{l}\text { bark, leaves, resin, stem, } \\
\text { root }\end{array}$ & NDV & Bakari et al., 2012 \\
\hline 10. & Cladosiphon okamuranus & cell wall & NDV & Elizondo-Gonzalez et al., 2012 \\
\hline 11. & Capsicum spp. & & variety of viruses & Lans et al., 2007 \\
\hline 12. & Cucumis metuliferus & ripe fruit & NDV & Chen et al., 2010 \\
\hline 13. & Cassia tora & & NDV & Lans, 2003 \\
\hline 14. & Euphobia ingens & branches & NDV & Lans et al., 2007 \\
\hline 15. & Echinacea purpurea & aerial parts & $\begin{array}{l}\text { improve resistance against NDV, food } \\
\text { uptake, decrease of mortality }\end{array}$ & Fard et al., 2010 \\
\hline 16. & Glycyrrhiza glabra & root & $\begin{array}{l}\text { inhibition of virus gene expression, } \\
\text { replication, attachment }\end{array}$ & Omer et al., 2014 \\
\hline 17. & Momordica balsamina & fruit pulp, leaves & NDV & Chollom et al., 2012 \\
\hline 18. & Moringa oleifera & seeds & NDV & Chollom et al., 2012 \\
\hline 19. & Nauclea latifolia & leaves & NDV & Onu et al., 2014 \\
\hline 20. & Ocimum sanctum & leaves & NDV & Jayati et al., 2013 \\
\hline 21. & Psidium guajava & leaves & NDV & Chollom et al., 2012 \\
\hline 22. & Thymus vulgaris & oil & NDV, HSV-1/HSV-2 & Rezatofighi et al., 2014 \\
\hline 23. & Withania somnifera & leaves, roots & NDV & Mustaq et al., 2012 \\
\hline
\end{tabular}

virulent strains show low sensitivity towards host proteases so damage is not so severe and it is restricted to only certain types of cells.

Lysine (K) or arginine (R), and phenylalanine (F) localised at the position 113-116, 117 are important amino acids of virulent NDV. In virulent strains, existence of basic amino acids at these sites means that cleavage can be affected by proteases present in host tissues (OIE, 2012). OIE accepts the cleavage sequence of $\mathrm{F}$ protein as key factor for virulence identification.

\section{Prevention and mechanisms in the treatment of NDV}

Standard precautionary procedures are necessary to avert ND in flocks. Birds from commercial farms should be separated from the domestic birds, pet birds and wild birds. Workers should also evade contact with any birds outside the farm. Birds should be kept in special proof houses with minimized movement, they should be provided with sterilised food and water supplies and clean medical kits are used before entering the farm. Pests like insects and mice must be controlled and employees if possible, should change clothing before entering the farm (Ashraf and Shah, 2014).

Vaccines are used to prevent the ND all over the world (Shim et al., 2011; Xiao et al., 2013). The vaccination can prevent the birds from clinical signs but cannot stop the main source of infection which is virus replication and shedding (Chukwudi et al., 2012). Anti-NDV antibody concentrations significantly maintain the anti-NDV maternal antibody titers of progeny which protect the chicks from illness in first week of life. Outbreaks are constantly occurring despite of extensive vaccination (Shabbir et al., 2012). Poultry producers are using different combinations of live and inactivated vaccines in a flock to overwhelm this problem.

\subsection{Plants used in NDV treatment}

World Health Organization (WHO, 2008) estimated that $80 \%$ of the world depends on traditional methods as their primary health care according to geographical restraints in Asian and African countries (Meneses et al., 2009). Based on knowledge, experience and indigenous cultural beliefs in traditional medicine is used to prevent, treat and diagnose 
physical and mental illnesses and maintain human health (WHO, 2008). Today there is a huge collection of medicinal plants with broad spectrum of antiviral activity. Crude drugs from a variety of plants have been formulated and used for centuries against several human illnesses and diseases. Plants indeed provide an enormous source of novel compounds that may have the potential to treat diseases (Newman and Cragg, 2007).

\section{Overview of plant species used in anti-NDV treatment}

The use of herbs and plants as medicine to cure the ailments is very popular throughout the world, as they usually have no harmful effects. The successful studies document that the medicinal plants of different species have antiviral efficacy and can be used against NDV.

\subsection{Azidarachta indica}

Azidarachta indica is a hardy plant and member of the Milaceae family. It is native to Pakistan (throughout Sindh, lower Baluchistan, and Southern Punjab and Southern North-West Frontier Province (Durrani et al., 2008) and India and also found in some parts of Africa. It is commonly known as Neem and a fast growing tree with final length of 15-20 m, growing in tropical and semi-tropical regions.

A. indica has many biological compounds (Senthil et al., 2006). Different parts of $A$. indica has been demonstrated to contain more than 140 compounds, like nimbin, nimbindin, azadiractin, and quercetin (Makeri et al., 2007), which have antihelminth, antiprotozoal, antioxidant, antifungal, antimicrobial, spermicidal, and insecticidal properties (Bonsu et al., 2012). However, as observed by virus inhibition methods, its antiviral compounds are insufficient for some viruses (Rao et al., 1969). Research revealed that it's methanolic extract of leaves and seed extracts in chloroform and hexane act as antivirals, however with obvious host cytotoxicity. Samples with concentrations exceeding 3-4 $\mu \mathrm{g} /$ egg significantly subdue NDV. In chicken embryos, inhibitory concentration $\left(\mathrm{IC}_{50}\right.$ ) and toxic concentration $\left(\mathrm{TC}_{50}\right)$ for $A$. indica were $4 \mu \mathrm{g} / \mathrm{egg}$ and $300 \mu \mathrm{g} / \mathrm{egg}$, respectively (Wafaa et al., 2007).

\subsection{Acacia nilotica}

Acacia nilotica is a single stemmed plant, widespread in tropical and subtropical areas of Asia (from Pakistan and India), Africa, Australia and Kenya. It is commonly termed as Kikar which is tannin rich medicinal plant.

The extract of plant in methanol has high antiviral activity against fowl viruses (Mohamed et al., 2010). Hemagglutina- tion assay was used to calculate the reduction of viability in the viral growth in presence or absence of the extract. The cytotoxicity of each extract was determined by the presence of the CPE. The methanol extract of A. nilotica in Vero cells showed non-cytotoxic concentration and significant inhibitory effect against the tested virus at the concentration of $40 \mu \mathrm{g} / \mathrm{ml}$. These results indicated that $A$. nilotica has significant inhibitory effect on the replication of NDV (Saeed, 2007).

\subsection{Adansonia digitata}

Baobab tree is regional name of Adansonia digitate. It belongs to the Malvaceae family and it is native to Africa. It is used as medicinal plant in Africa to cure many infectious diseases (Vimalanathan and Hudson, 2009). Its parts like bark, fruit pulp, leaves and seeds have medicinal as well as nutritional usages.

Methanolic extract of rootbark of $A$. digitate was checked for its antiviral potential by treating it against 175 specific antibodies in embryonated chicken eggs (ECEs) infected with NDV strain. After $2 \mathrm{~h}$ exposure of the virus to eight concentrations of the extract and after $24 \mathrm{~h}$ incubation the mortality was observed. The $100 \mathrm{EID}_{50}$ concentration of the virus and the highest concentration of the extract were inoculated as positive and negative controls, respectively. All eggs inoculated with the virus alone as well as 5 and $2 \mathrm{mg} / \mathrm{ml}$ extract/virus suspensions, died after $72 \mathrm{~h}$ post inoculation, while no mortality was observed amongst those inoculated with 250 and $200 \mathrm{mg} / \mathrm{ml}$ virus/extract suspensions as well as those inoculated with the extract alone. This study showed that methanolic rootbark extract of $A$. digitata has antiviral activity against NDV in ovo, particularly when used at dose rates of 200 and $250 \mathrm{mg} / \mathrm{ml}$ (Sulaiman et al., 2011).

\subsection{Anthocleista nobilis}

Anthocleista nobilis, also called candelabrum or cabbage tree (in English) belongs to the Loganiaceae family. The root is pharmacologically the most active and it is mostly used as a purgative and dietary supplement, or a poison antidote. Ethanolic extract of $A$. nobilis was considered as good for the dealing with ND in fowl. Results indicated that the biochemical components present in this extract had significant effect in remedy of poultry caused by NDV (Ayodele et al., 2012).

\subsection{Aloe secundiflora}

Aloe secundiflora reduced the mortality rates of NDV infected birds. Treatment or pre-treatment with A. secundiflora can reduce mortality to $21.6-31.6 \%$. The gel of $A$. secundiflora contains polysaccharides with antiviral efficacy and the outer sap contains bioactive compounds as anthraquinone 
glycosides. Anthraquinones have potential to damage the envelope of viruses like influenza virus, NDV, HSV-1, HSV-2 (Waihenya et al., 2002).

\subsection{Aloe hijazensis}

Aloe hijazensis belongs to the Aloe vera family. Its different parts were examined for antiviral activity against NDV. Root, leaves, flowers, and flower peduncles posses many bioactive molecules. Flowers and peduncles contain 13 different compounds while roots and leaves contain chromones, anthrones, anthraquinones and flavonoids. Pathogen free embryonated eggs were used for evaluation of $A$. hijazensis flowers, peduncles, leaves, and roots against NDV. It was proved that extracts of leaves and flowers had better antiviral activity against NDV than roots and peduncles (Abd-Alla et al., 2012).

\subsection{Artemisia annua L.}

Afsanteen (Artemisia annua L.) is the member of the Asteraceae family. It is native to temperate Asia and some parts North America. There is only limited information about the antiviral activity testing of A.annua however its anti-NDV activity was proved. The extracts of compounds were prepared by decoction methods and results revealed that due to presence of bioactive components, ethanolic extracts inhibit NDV propagation in embryos and show no side effects (Liu and Genqiang, 2009).

\subsection{Curcuma longa}

Curcuma longa (Turmeric), a primeval coloring spice, is traditionally used as a remedy worldwide (Araújo and Leon, 2001). Turmeric contains curcumin as important derivative which has efficient antiviral activity against different viruses (Dairaku et al., 2010). Hubbard chicks divided into six groups (control group, group of chicks vaccinated with NDV, group of chicks vaccinated with MDV Rispen strain, group of chicks vaccinated with MDV and NDV, group of chicks vaccinated with MDV and treated with C. longa and group of chicks vaccinated with NDV and treated with $C$. longa) were used in the experiment for antiviral activity of $C$. longa. The results indicated that the powder of $C$. longa increased the immune response against the infection (Madbouly et al., 2011).

\subsection{Commiphora swynnertonii}

Commiphora swynnertonii is found in tropical and subtropical areas of Asia and north Eastern Africa. C. swynnertonii species are characteristic for shrub appearance with spines, pale grey bark and brownish resinous exudate (Moshi et al., 2010).
Different parts of C. swynnertonii as root, bark, leaves, resin and stem were tested to cure NDV by in ovo assay in ECEs. The eggs were divided into 7 groups in which five groups were treated with extracts of different parts of C. swynnertonii and two groups were left as positive and negative controls. Embryos were checked daily and weighted 5 days after inoculation and some eggs were left to hatch. For hemagglutination and hemagglutination inhibition assay, allantoic fluid from tested eggs and serum from hatched chickens were used. Results showed that mean weight and survival was higher in extract treated eggs than in infected control group. The presence of extract also lowered the virus titre. Moreover, no virus was detected in allantoic fluid of eggs treated with resin extract. Further, bark and root extracts were assumed to be efficient in virus clearance since no antibodies were observed in the blood of chicks (Bakari et al., 2012).

\subsection{Cladosiphon okamuranus}

Cladosiphon okamuranus is type of edible seaweed, which is naturally produced in Okinawa, Japan. Research indicates that presence of fucoidan in this species has antiviral potential against NDV (La Sota strain) and restricts replication mainly between 0-60 min after infection. Reduced HA and NP protein expression was found in $48 \%$ of viral infections (Elizondo-Gonzalez et al., 2012).

\subsection{Capsicum spp.}

Capsicum spp. is widely used to treat variety of diseases, often in combination with other plants. Capsaicin, one of the constituents of Capsicum spp., is thought to improve resistance to viral disease in poultry (Lans et al., 2007).

\subsection{Cucumis metuliferus}

This plant is also known as horned melon or kiwano and belongs to the Cucurbitaceae family. Ripe fruit is similar to cucumber but with yellow to orange skin and lime green, jelly-like flesh with a sour taste. Various phytochemicals present in this plant account for its different medicinal characteristics. Alkaloids present in fruit pulp of C. metuiferus have antiviral properties. The chickens infected with NDV were treated with extracts of kiwano to show the antiviral efficiency. The results revealed that alkaloids of this plant have strong anti-viral effects and reduce the signs of disease at concentration of $60 \mathrm{mg} / \mathrm{kg}$ (Chen et al., 2010).

\subsection{Cassia tora}

Cassia tora is a dicot legume found mainly in South-East Asia. It contains sufficient quantities of anthraquinones and 
has anti-NDV activity. Other species with anti-ND virus activity include C. auriculata and C. fistula (Lans et al., 2007).

\subsection{Euphorbia ingens}

Euphorbia ingens belongs to the Euphorbiaceae family and is indigenous to dry ranges of South Africa. It is also called the candelabra tree. The crushed and soaked (overnight in water) branches of $E$. ingens given to NDV infected chickens in drinking water decreased the mortality by $38.4 \%$ (Lans et al., 2007).

\subsection{Echinacea purpurea}

Echinacea purpurea is known as purple coneflower belonging to sunflower family (Compositae). Its ethanolic extract contains set of essential amino acids such as isoleucine, lysine, glutamic acid, proline, serine, phenylalanine, and threonine which have significant effects in NDV clearance. Investigational studies stated that use of E. purpurea enhanced resistance against virus and significantly improved food uptake rates and amended rates of mortality in infected fowl (Fard et al., 2010).

\subsection{Glycyrrhiza glabra}

Glycyrrhiza glabra is generally known as licorice, Malathi (in Punjabi) and sweetwood, is a native plant of some regions of Asia and Europe. It is used as flavour in tobacco products, drinks and candies. Its medicinal properties are found in the main taproot which is soft and fibrous.

Hemagglutination inhibition test of ECEs showed that 60 $\mathrm{mg} / 100 \mathrm{ml}$ of aqueous extract of G. glabra exhibited anti-viral activity against the virus (Omer et al., 2014). It contains more than 20 tri-terpenoids and about 300 flavonoids. But only two triterpenoids, glycyrrhizin (Wang et al., 2015) and 18$\beta$-glycyrrhetinic acid (Feng et al., 2013) have been reported to have antiviral effects. They can ablate virus activities by inhibiting virus gene expression and replication, reducing attachment force and stress, and reducing HMGB1 binding to DNA. They can also improve host cell activities by blocking the degradation of I $\mathrm{B}$, activating T lymphocyte proliferation and decreasing host cell apoptosis (Omer et al., 2014).

\subsection{Momordica balsamina}

It is herbaceous climber plant, a member of Curbitacae family endemic to Northern Nigeria (Bokhari and Ahmed, 1980). Phytochemical analysis revealed that its fruit, leaves and seeds contain lectins, steroids, saponins, glycosides and tannins. Presence of alkaloids, flavonoids, saponins and tannins considers them as innovative antiviral mediators (Jassim and Naji, 2003). To prove the antiviral ability of fruit and leaf extracts of M. balsamina, fibroblastic cell lines from chicken embryos were used. Results revealed that both extracts inhibited the infection at concentration of $10 \mathrm{mg} / \mathrm{ml}$ and $20 \mathrm{mg} / \mathrm{ml}$ correspondingly. Further detailed investigations revealed the ability of the extract to avert the adhesion of virus on host cell surface (Chollom et al., 2012b).

\subsection{Moringa oleifera}

Moringa oleifera also known as "miracle tree" has all essential amino acids, vitamins, calcium and all nutrients required concentrated in its leaves (Shirin and Hitesh, 2016). It is also known as Sohanjana, a member of the Moringacea family. Plant is endemic to Pakistan and India. Southern Punjab is considered as origin of Moringa plant. Aqueous seed extract of $M$. oleifera was analysed for anti-NDV activity in in ovo assay. Antibody production and virus clearance decreased in concentration dependent manner. The extract also enhanced the immunity efficiency (Chollom et al., 2012a).

\subsection{Nauclea latifolia}

Nauclea latifolia is a shrub or evergreen small tree found in tropical forests of Africa. The dried powdered material of $N$. latifolia has been shown to have antiviral effects against wild type of $\mathrm{ND}$. $\mathrm{EID}_{50} / \mathrm{ml}$ was determined by end point analysis. In literature, test for toxicity demonstrates that three different concentrations of hot aqueous and ethanolic extract of $N$. latifolia were able to minimize virus loads. Both extracts with concentrations of up to $125 \mathrm{mg} / \mathrm{ml}$ were toxic for chicken eggs. Ethanolic extracts had better antiviral activity than hot water extracts (Onu et al., 2014).

\subsection{Ocimum sanctum}

Ocimum sanctum called also Holy basil (English) and Tulsi (Hindi) cultivated primarily in India and tropical and subtropical regions is regarded as scared. It has therapeutic representations in primeval cultures of many countries. Antiviral efficiency of $O$. sanctum was studied by administration of hot aqueous leave extract of $O$. sanctum to chicken embryo fibroblast monolayer culture. Hemagglutination assay was used for estimation of viral concentration in medium, while examination of cytopathic properties of NDV was done on chicken embryo fibroblast monolayer. Results indicated that concentration of $10 \mathrm{mg} / \mathrm{ml}$ or less of hot aqueous leaves extract prevents the NDV cytopathic effect and restricts NDV replication in fibroblasts (Jayati et al., 2013).

\subsection{Psidium guajava}

Psidium guajava or common guava is commonly present around the globe. It is a common shade tree in yard gardens 
in the tropical areas. The pharmacologically beneficial substances such as alkaloids, tannins, flavonoids, saponins and other compounds in the leaves are accounted for the diverse claims and applications of parts of the plant in local treatment of diseases. Antiviral efficacy of $P$. guava leaf extract against NDV was performed by in ovo assay. Extracts prevented viral replication in ECEs at concentration of $250 \mathrm{mg} / \mathrm{ml}$ and 200 $\mathrm{mg} / \mathrm{ml}$. Embryo survival improved in dose dependent manner and the presence of the extract inhibited the antibody production in hatched chicks (Chollom et al., 2012).

\subsection{Thymus vulgaris}

Thymus vulgaris is known as Thyme. It is indigenous to Mediterranean countries, North Africa and Asia. It grows to the height of $50 \mathrm{~cm}$ with woody branched stems. The flowers are purple to pink. It has essential oils and bioactive substance that possess antioxidant and antimicrobial activities. These substances can be active against microorganisms such as fungi, yeasts, viruses and bacteria. T. vulgaris was found to be effective against HSV-1/HSV-2 and NDV. Essential oils of this plant were able to disrupt viral envelopes and prevented attachment of the virion to the host cell (Rezatofighi et al., 2014).

\subsection{Withania somnifera}

Withania somnifera is used as medicinal plant worldwide, belonging to the Solanaceae family. It is commonly known as Asgandha or asgund. The major compound in roots and leaves of $W$. somnifera are alkaloids, which are responsible for its boosting efficiency. It has been demonstrated that this plant enhanced production of the white and red blood cells (Senthilnathan et al., 2006). W. somnifera aqueous extract administered to chickens in drinking water, improved the hemoglobin, body weight and total lymphocytes count. W. somnifera induced healthier food uptake, body weight, haematological profile and better immune status of chickens (Mustaq et al., 2012).

\section{Conclusions}

Data presented in this review highlight the incidence of ND worldwide and medicinal plants used as a source for combating of ND. Here, 23 plants are discussed with their various parts and different extracts used against NDV. To find more active and less toxic anti-NDV remedies it is essential to utilize the novel antiviral drugs from bioactive components of the plants. Consequently substantial attention was paid on prospective abilities of plants with active components that exhibit antiviral virtues against NDV. In addition, in vivo and in vitro testing was followed by toxic- ity assays. After optimization and appropriate approach, promising compounds of novel antiviral products against NDV may be revealed. Drugs derived from medicinal plants around the continents, will be beneficial to individuals and also for nations. Although to utilize the antiviral compounds of plants, the facts of mechanisms of virus infection require to be understood in order to ease the exploration and advancement of most suitable drugs. Further investigation is desired to reveal how to target the proper regimens to avert the spread viral infections.

\section{References}

Abd-Alla HI, Abu-Gabal NS, Hassan AZ, El-Safty MM, Shalaby NMM, Arch. Pharma Res. 35, 1347-1354, 2012. https:// doi.org/10.1007/s12272-012-0804-5

Ahmed A, Khan TA, Kanwal B, Raza Y, Akram M, Rehmani SF, Lone NA, Kazmi SU, Int. J. Agric. Biol. 11, 326, 2009.

Al-Habeeb MA, Mohamed MHA, Sharawi S, Vet. World. 6, 239-243, 2013. https://doi.org/10.5455/vetworld.2013.239-243

Alexander DJ, In Saif YM (Ed.): Diseases of Poultry. Vol. 11. pp. 63-80, 1993.

Alexander DJ, In Calnek BW, Barnes HJ, McDougall LR, Saif YM, Beard CW (Eds): Diseases of Poultry, 1997.

Alexander DJ, Rev. Sci. Tech. 19, 443-462, 2000. https://doi. org $/ 10.20506 /$ rst.19.2.1231

Alexander DJ, Manvell RJ, Banks J, Collins MS, Parsons G, Cox B, Frost EC, Speidel EC, Ashman S, Aldous EW, Avian Pathol. 28, 501-511, 1999. https://doi.org/10.1080/03079459994542

Alexander DJ, Senne DA: In Diseases of Poultry, 2008.

Araújo CAC, Leon LL, Memorias do Instituto Oswaldo Cruz, 96, 723-728, 2001. https://doi.org/10.1590/S0074$\underline{02762001000500026}$

Ashraf A, Din MSU, Habib M, Hussain M, Mahboob S, Al-Ghanim K, Bra. Arch. Biol. Technol. 59, 2016. e16150452.

Ashraf A, Shah MS, Afr. J. Microbiol. Res. 8, 411-416, 2014. https:// doi.org/10.5897/AJMR2013.6540

Ayodele PO, Okonko IO, Odu NN, Banso A, Ann. Biol. Res. 3, 20-30, 2012.

Anonyme (OIE), 10/17/2011. www.old.caribvet.net/en/diseases/ newcastlediseases/geographical-distribution

Admin, https://fieldcasestudy.com/2017/05/18/bird-flu, 18, May 2017.

Bakari GG, Max RA, Mdegela RH, Phiri EC, Mtambo MM, Trop. Anim. Health Prod. 44, 1389-1393, 2012. https://doi. org/10.1007/s11250-012-0076-6

Beard CW, Hanson RP, In Hofstad MS, John H, Calnek BW, Reid WM, Yoder HW (Ed.): Editorial Board for the American Association of Avian Pathologists, pp. 452-470, 1984.

Bhaiyat MI, Ochiai K, Itakura C, Islam MA, Kida H, J. Avian Pathol. 23, 693-708, 1994. https://doi.org/10.1080/03079459408419038

Bokhari MH, Ahmed MSCH, Food plants in Borno state, Nigeria. Gulani Publishers, Lahore, India, pp. 31-32, 1980.

Bonsu FRK, Kagya-Agyemang JK, Kwenin WKJ, Zanu HK, World Appl. Sci. J. 19, 800-805, 2012. 
Boynukara B, Gulhan T, Coven F, Kiziroglu I, Durmus A, Turk. J. Vet. Anim. Sci. 37, 1-9, 2013.

Chollom CS, Agada GOA, Bot DY, Okolo MO, Dantong DD, Choji TP, Echeonwu BC, Bigwan EI, Lokason S, Banwat E, J. App. Pharma. Sci. 2, 45-49, 2012.

Cao Y, Gu M, Zhang X, Liu W, Liu X, J. Genome Announce. 1, e00180-12, 2013.

Catroxo MHB, Martins AMCRPF, Petrella S, Curi NA, Melo NA, Int. J. Morphol. 29, 628-635, 2011. https://doi. org/10.4067/S0717-95022011000200055

CFIA, Newcastle Disease Overview. Canadian Food Inspection Agency. 2014. http://www.inspection.gc.ca/animals/terrestrial-animals/diseases/reportable/nd/hazard-specificplan/newcastle-disease-overview/eng/1392661256688/ 1392661309738

CFSPH, Avian Paramyxovirus-1 Infection, Goose Paramyxovirus Infection, Ranikhet disease. Center for Food Security and Public Health, Iowa State University \& Institute for International Cooperation in Animal Biologics, pp. 1-9, 2016.

Chen Y, Wang D, Hu Y, Guo Z, Wang J, Zhao X, Fan Y, Guo L, Yang S, Sai F, Xing Y, Int. J. Biol. Macromol. 46, 425-428, 2010. https://doi.org/10.1016/j.ijbiomac.2010.02.004

Choi KS, Lee EK, Jeon WJ, Kwon JH, J. Vet. Sci. 11, 205-211, 2010. https://doi.org/10.4142/jvs.2010.11.3.205

Chollom SC, Agada GOA, Gotep JG, Mwankon SE, Dus PC, Bot YS, Nyango DY, Singnap CL, Fyaktu EJ, Okwori AEJ, J. Med. Plants Res. 6, 3870-3875, 2012a. https://doi.org/10.5897/ JMPR12.394

Chollom SC, Olawuyi AK, Danjuma LD, Nanbol LD, Makinde IO, Hashimu GA, Alesa MU, Esilonu JT, Ogundeji EB, Kwatjel JS, J. Adv. Pharma. Edu. Res. 2, 82-92, 2012 b.

Chukwudi OE, Chukwuemeka ED, Mary U, Pak Vet. J. 32, 354356, 2012.

Cornell University College of Veterinary Medicine: http://partnersah.vet.cornell.edu/avian-atlas/taxonomy/term/562

Dairaku I, Han Y, Yanaka N, Kato N, Biosci. Biotechnol. Biochem. 74, 185-187, 2010. https://doi.org/10.1271/bbb.90568

Doyle TM, J. Comp. Pathol. Therap. 48, 1-22, 1935. https://doi. org/10.1016/S0368-1742(35)80001-5

Durrani FR, Sultan A, Akhtar S, Jan M, Chand N, Durrani Z, Sarhad j. Agric. 24, 655-659, 2008.

Elizondo-Gonzalez R, Cruz-Suarez LE, Ricque-Marie D, MendozaGamboa E, Rodriguez-Padilla C, Trejo-Avila LM, Virol. J. 9, 9-307, 2012. https://doi.org/10.1186/1743-422X9-307

Erickson GA, Mare CJ, Gustafson GA, Miller LD, Proctor SJ, Carbrey EA, Avian Dis. 21, 642-654, 1977. https://doi. org/10.2307/1589424

ESP: Ministry of Finance. Government of Pakistan, Islamabad. Chapter 2, 29-33, 2015-2016.

Fard MHB, Feizi A, Bijanzad P, J. Vet. Res. 65, 119-122, 2010.

Feng YC, Chih WK, Chai CL, Shieh DE, Hong YM, San CJ, J. Ethnopharmacol. 148, 466-473, 2013. https://doi. org/10.1016/j.jep.2013.04.040

Hadipour MM, Habibi GH, Golchin P, Hadipourfard MR, Shayanpour N, Int. J. Anim. Vet. Adv. 3, 69-72, 2011.
Hitchner SB, Avian Dis. 48, 1-8, 2004. https://doi.org/10.1637/6100

Herenda DC, Chambers PG, Food \& Agriculture Org. 1994. www. fao.org

Jassim SA, Naji MA, J. Appl. Microbiol. 95, 412-427, 2003. https:// doi.org/10.1046/j.1365-2672.2003.02026.X

Jayati, Bhatia AK, Amit K, Goel A, Sandeep G, Anu R, Int. J. Microbiol. Immunol. Res. 2, 51-55, 2013.

Jordan FTW, In Poultry Disease. Cambridge University Press, Great Britain, pp. 121-136, 1990.

Kaleta EF, Baldauf C, In Alexander DJ (Ed.): Newcastle Disease. Kluwer Academic Publishers, Boston, MA, 1998.

Kamal M, New vaccines needed to fight Newcastle disease in Pakistani birds: Sci. dev. Net. 2013. http://www.scidev. net/south-asia/livestock/news/new-vaccines-needed-tofight-newcastle-disease-in-pakistani-birds.html

Kapczynski DR, Afonso CL, Miller PJ, Deve. Comp. Immunol. 41, 447-453, 2013. https://doi.org/10.1016/j. dci.2013.04.012

Khan MY, Arshad M, Hussain I, Mahmood MS, Int. J. Agric. Biol. 13, 491-497, 2011.

Khan TA, Rue CA, Rehmani SF, Ahmad A, Wasilenko JL, Miller PJ, Afonso CL, J. Clin. Microbiol. 48, 1892-1894, 2010. https://doi.org/10.1128/JCM.00148-10

Kouwenhoven B, McFerran JB, McNulty MS, Elsev. Sci. Amsterdam and New York, 1993.

Lans C, Khan TE, Curran MM, McCorkle CM, Vet. Herbal. Med. 17-32, 2007.

Li X QY, Yu A, Chai T, Zhang X, Wangb JLD, Wang H, Wang Z, Song C, J. Virol. Methods 158, 1-5, 2009. https://doi. org/10.1016/j.jviromet.2009.01.011

Liu Y, Genqiang Y, Mod. App. Sci. 3, 176-178, 2009.

Lucas AM, Jamroz C, Atlas of avian hematology. 1961. http://partnersah.vet.cornell.edu/avian-atlas/taxonomy/term/562\#/ disease/Newcastle_Disease

Madadgar O, Karimi V, Nazaktabar A, Kazemimanesh M, Ghafari MM, Dezfouli SMA, Hojjati P, Avian Pathol. 42, 27-31, 2013. https://doi.org/10.1080/03079457.2012.752791

Madbouly HM, Saif MA, Hussein AS, Int. j. Virol. 7, 176-183, 2011. https://doi.org/10.3923/ijv.2011.176.183

Makeri HK, Maikai VA, Nok JA, Afr. J. Biotechnol. 6, 2324-2327, 2007. https://doi.org/10.5897/AJB2007.000-2364

Martin PAJ, Proceedings of an international workshop held in Kuala Lumpur, Malaysia 6-10 October 1991, pp. 40-45. 1992.

Mase M, Imai K, Sanada Y, Sanada N, Yuasa N, Imada T, Tsukamoto K, Yamaguchi S, J. Clin. Microbiol. 40, 3826-3830, 2002. https://doi.org/10.1128/JCM.40.10.3826-3830.2002

McFerran JB, McCracken RM, In Alexander DJ (Ed.): Newcastle Disease. Kluwer Academic Publishers, Boston, pp. 147160, 1988. https://doi.org/10.1007/978-1-4613-1759$\underline{3 \_10}$

Meneses R, Ocazionez RE, Martinez JR, Stashenko EE, Ann. Clin. Microbiol. Antimicrob. 8, 8, 2009. https://doi. org/10.1186/1476-0711-8-8

Mohamed LT, Bushra EIS, Abdelrahman MN, Eur. Asian J. BioSci. 4, 8-16, 2010.

Moshi M, Innocent E, Magadula J, Otieno D, Weisheit A, Mbabazi P, Nondo R, Tanzania J. Health Res. 12, 63-67, 2010. 
Munir M, Shabbir MZ, Yaqub T, Shabbir MAB, Mukhtar N, Khan MR, Berga M, J. Virol. 86, 13113-13114, 2012. https://doi. org/10.1128/JVI.02358-12

Mustafa MY, Ali SS, Punjab Univ. J. Zool. 20, 177-180, 2005.

Mustaq M, Durrani FR, Imtiaz N, Sadique U, Hafeez A, Akhtar S, Ahmad S, Pak. Vet. J. 32, 70-72, 2012.

Nagai Y, Ogura H, Klenk H-D, J. Virol. 69, 523-538, 1976. https:// doi.org/10.1016/0042-6822(76)90482-7

Narayanan MS, Parthiban M, Sathiya P, Kumanan K, J. Veterinarski Arhiv. 80, 51-60, 2010.

Naveen KA, Singh SD, Kataria JM, Barathidasan R, Dhama K, Trop. Anim. Health Prod. 10, 1-6, 2013.

Newman DJ, Cragg GM, J. Nat. Prod. 70, 461-477, 2007. https:// doi.org/10.1021/np068054v

Numan M, Zahoor MA, Khan HA, Siddique M, Pak Vet. J. 25, $55,2005$.

Ocazionez REM, Torres FA, Stashenko E, Mem. Inst. Oswaldo Cruz. 105, 304-309, 2010. https://doi.org/10.1590/S0074$\underline{02762010000300010}$

Office International des Epizooties (OIE), Terrestrial Animal Health Code. World Organization for Animal Health, 2013.

Office International des Epizooties (OIE), Manual of Diagnostic Tests and Vaccines for Terrestrial Animals. Chap 2.3.14, pp. 555-574, 2012.

Omer MO, Almalki WH, Shahid I, Khuram S, Altaf I, Imran S, Pharmacogn. Res. 6, 6-11, 2014. https://doi. org/10.4103/0974-8490.122911

Onu U, Nwiyi P, Erumaka I, Sky J. Microbiol. Res. 3, 1-5, 2014.

Patti JM, Avian Pneumoencephalitis, Exotic or velogenic Newcastle Disease. In Manual M (Ed.), 2014.

Perozo F, Merino R, Afonso CL, Villegas P, Calderon N, Avian Diseases 52, 472-479, 2008. https://doi.org/10.1637/8276022908-Reg. 1

Pham HM, Konnai S, Usui T, Chang KS, Murata S, Mase M, Ohashi K, Onuma M, Arch. Virol. 150, 2429-2438, 2005. https:// doi.org/10.1007/s00705-005-0603-0

Miller PJ, Decanini EL, Afonso CL, Infect. Gene Evol. 10, 26-35, 2010. http://ddr.nal.usda.gov/bitstream/10113/44041/1/ IND44408321.pdf

Qiu X, Sun Q, Wu S, Dong L, Hu S, Meng C, Wu Y, Liu X, Virol. J. 8, 1-11, 2011. https://doi.org/10.1186/1743-422X-8-117

Rao AR, Sukumar S, Paramasivam TV, Kamalakshi S, Parashuraman AR, Shantha M, Indian J. Med. Res. 57, 495-502, 1969.

Rezatofighi SE, Seydabadi A, Seyyed Nejad SM, Jundishapur J. Microbiol. 7, e9016, 2014. https://doi.org/10.5812/jjm.9016

Robinson MM, Zhang X, WHO Geneva 2011. WHO/EMP/ MIE/2011.2.3. 2011.
Saeed AMM, Department of Medicine Pharmacology and Toxicology, Master's Degree Thesis in Veterinary Science. University of Khartoum, 2007.

Senthil NS, Kalaivani K, Chung PG, Murugan K, Chemosphere 62, 1388-1393, 2006. https://doi.org/10.1016/j. chemosphere.2005.07.009

Senthilnathan P, Padmavathi R, Banu SM, Sakthisekaran D, Chemico-Biol. Interact. 159, 180-185, 2006. https://doi. org/10.1016/j.cbi.2005.11.003

Shabbir MZ, Goraya MU, Abbas M, Yaqub T, Shabbir MA, Ahmad A, Anees M, Munir M, Pak J. Virol. 86, 13828-13829, 2012. https://doi.org/10.1128/JVI.02626-12

Shim JB, So HH, Won HH, Mo I, J. Avian Pathol. 40, 565-572, 2011. https://doi.org/10.1080/03079457.2011.616187

Shirin Q, Hitesh S, Int. J. Chem. 64-71, 2016.

Sulaiman LK, Oladele OA, Shittu IA, Emikpe BO, Oladokun AT, Meseko CA, Afr. J. Biotechnol. 10, 4256-4258, 2011.

Shabbir MZ, Zohari S, Yaqub T, Nazir J, Shabbir, MAB, Mukhtar N, et al., Virol. J. 10, 170, 2013. https://doi.org/10.1186/1743422X-10-170

Ullah S, Ashfaque M, Rahman SU, Akhtar M, Rehman A, Pak Vet. J. 24, 28-30, 2004.

USAHA, Foreign Animal Diseases. 7th (Ed.). Boca Publications Group, Boca Raton, F.L., 2008.

Vimalanathan S, Hudson JB, J. Med. Plants Res. 3, 576-582, 2009.

Wafaa AH, Howaida IA, Hassan A, El-safty MM, Aust. J. Basic App. Sci. 1, 801-812, 2007.

Waheed U, Siddique M, Arshad M, Ali M, Saeed A, Pak J. Zool. 45, 339-344, 2013.

Waihenya RK, Mtambo MM, Nkwengulila G, J. Ethnopharmacol. 79, 299-304, 2002. https://doi.org/10.1016/S0378-8741(01)00370-1

Wang L, Yang R, Yuan B, Liu Y, Liu C, Acta Pharma. Sinica. B. 5, 310315, 2015. https://doi.org/10.1016/j.apsb.2015.05.005

World Health Organization (WHO), Chapter 4. Public Policies for the Public's Health, pp. 63-76, 2008.

Xiao S, Paldurai A, Nayak B, Mirande A, Collins PL, Samal SK, J. Genome Announc. 1, 1-2, 2013.

Yan Z, Du Y, Zhao Q, Fan R, Guo W, Ma R, Wang X, Zhu R, Pak Vet. J. 31, 280-286, 2011.

Yune N, Abdela N, J. Vet. Sci. Technol. 8, 2017.

Zanetti F, Rodriguez M, King DJ, Capua I, Carrillo E, Seal BS, Berinstein A,Virus Genes. 26, 199-206, 2003. https://doi. org/10.1023/A:1023495615729

Zhang Y, Zhang S, Wang X, Zhang G, J. Virol. 86, 13849-13850, 2012. https://doi.org/10.1128/JVI.02663-12 